\title{
The Market-oriented Specialty Construction of Characteristic Applied Undergraduate
}

\author{
Yangyang Ge \\ Graduate School of Harbin University of Science and Technology, Harbin University of Science and \\ Technology, Harbin, 150080, China \\ email:Geyangyang92356@163.com
}

Keywords: Market; Characteristic Applied Undergraduate; Specialty Construction

\begin{abstract}
Characteristic applied undergraduate is a product of strengthening college classification guidance, leading college dislocation development and achieving its own characteristics, which is under the circumstances of structuring regional economic development and the demand for industrial restructuring. The specialty construction of characteristic applied undergraduate has a direct influence on the cultivation of its talents. Starting from the orientation function and feedback function of market in constructing characteristic applied undergraduate specialty, this paper explores the ways market gets involved in the specialty construction of characteristic applied undergraduate.
\end{abstract}

With the popularization of higher education in our country, applied higher education has been an important component of our higher education development. Applied undergraduate education which differs from higher vocational education and research university education, is the education training high-grade specialized talents who are needed in the development of society and economy. The specialty construction of applied undergraduate is critical to the formation of university characteristics and has a direct influence on the training quality of applied undergraduate talents.

\section{The Specialty Construction of Characteristic Applied Undergraduate}

The concept "Characteristic applied undergraduate" is put forward in the process of actively carrying out the construction of applied undergraduate universities. The characteristic applied undergraduate construction has been made in pilot institutions including firstly Heilongjiang Institute of Technology and Oriental College. On this basis, the construction of four characteristic applied undergraduate institutions was added. "Characteristic applied undergraduate" construction focuses on characteristic. Government, universities and market are three main factors influencing the construction of characteristic applied undergraduate, among which market is the critical one and plays a more and more important role in constructing characteristic applied undergraduate. From the perspective of market, the talents cultivated by characteristic applied undergraduate are just like characteristic "commodities" which get involved in the market competition and are subject to market discipline. The market factors make us think deeply about specialty construction from such different levels as society, universities and industries as well as conduct proper settings and integration considering the features of educational essence, social needs and industrial development.

\section{The Role of Market in Specialty Setup and Adjustment of Characteristic Applied Undergraduate}

As a critical factor influencing the specialty construction of characteristic applied undergraduate, market plays an important role in the various parts of specialty construction. Market demands not only lead the construction direction of characteristic applied undergraduate, but also have feedback effects on specialty construction.

A. The guide function of market in specialty construction of characteristic applied undergraduate 
Talent training in universities should meet the requirements of market. From the perspective of market discipline, talents are the characteristic "commodities" participating in the market competition. When some commodity' demand exceeds its supply, that means there is a large demand for this commodity whose output needs to be strengthened. On the contrary, when some commodity's supply exceeds its demand, that means the demand for the commodity gets saturated and some related adjustment should be made to reduce or stop the production of this commodity. University, like the producer of commodity, makes proper adjustment and integration on specialty according to the market demand so as to cultivate talents who can better meet the demand of market which guides the specialty construction of universities. At the same time, the specialty construction of applied undergraduate is affected by industrial restructuring and optimization as well as the rapid growth of regional economy. With the constant adjustment and optimization of industrial structure, modern industrial technology has an increasing dependence on technical equipment and a prominent demand for high-tech talents as well as the growing demand for industrial high-tech talents accompanying with the rapid development of regional economy. Under the circumstances, the specialty construction of characteristic applied undergraduate should be carried out in this direction and centered on "industry" in order to cultivate related talents.

B. The feedback function of market in the specialty construction of characteristic applied undergraduate

To see whether the specialty construction of characteristic applied undergraduate is reasonable and whether the specialty settings is appropriate as well as whether our trained talents are qualified enough to meet the demand of the market, the most direct criterion is the market and the most objective reflection is the graduates' employment rate. If the graduates' employment rate decreases, that means the market demand gets saturated towards such talents or the trained talents by the universities cannot meet the demand of the market, thus, the universities should make adjustment and integration on their specialty based on this information.

However, due to the dynamic of the market demand, and cyclical characteristic of higher education focus on cultivating talents is long, the feedback function from the market can only response for the market demand for talents during the period, lacking of long-term feedback information of the system. In order to make the feedback function of the market get maximum exertion, based on the importance function of the market in the specialty construction of the characteristic applied undergraduate, university should have a close relationship with market and set up a series of related measures system to protect this exertion of the function. Establishing talent market demand monitoring system, strengthening the construction of the characteristics of applied undergraduate university to take the initiative to adapt to social change requires for self development and the professional management mechanism of self adjustment.

\section{The Overall Involvement of the Market Factors in the Specialty Connotation Construction of Characteristic Applied Undergraduate}

Market factors amplify the pertinence and competitiveness of specialty construction of applied undergraduate. The applicability of specialty construction of applied undergraduate is the fundamental feature. It changed major setup for the past regarded "discipline" as a center but strengthen the major construction of making the "industry" as a center. Market factors involved in each link of the specific specialty construction, mainly includes the following several aspects.

A. Enterprise participate in the formulation of professional training goals and talent training specifications

Enterprise is an important subject of the market activities. Therefore, in the specialty construction of the characteristic applied undergraduate, they shall be as an important participant and join in each link of the professional construction. Unlike the specialty construction of ordinary undergraduate, in the process of the specialty construction of the characteristic applied undergraduate, not only need a large number of education experts and scholars to participate in but also need the subject of the market activity actively participate in, such as employing units and 
engineers who working on the front line, etc. Professional training goal and talent training specifications determine the direction of professional training talents, the training goals of specialty of the characteristic applied undergraduate emphasize basic knowledge and professional practice ability, and the second one is more important. Enterprise participate in the professional training goal can put the requirements of how the enterprise employ persons into the talents training goals, and refine the personnel training specifications, then the ability of training talents may have a definite quantitative standards.

\section{B. Take the market as the leader, "industry" as the center in major setup and integration}

The major setup of applied undergraduate has a characteristic by its applicability. To break the existing specialty setup centered on the subject, market should be seen as a dominant factor, surrounding the industry, being targeted to set up new specialties, integrating the old specialties, and giving new vitality to the specialty. According to the guidance function from the market and feedback function, the weak professions in greater competition compressing, adjustment or suspension, and adding or investing more strong professions in greater competition to keep characteristics of applied undergraduate professional have vigorous vitality.

\section{Market's influence on the course content and teaching methods}

Market factors involved in the construction of the course content, require reforming the existing curriculum content, on the basis of reserving foundation courses, professional foundation courses, setting more percentage of practical courses. This is determined by the talents training goals of characteristic applied undergraduate. The training talent of characteristic applied undergraduate should have strong employment competitiveness and capacity of sustainable development at the same time. Talents who have strong employment competitiveness should find the problems in practice and have the ability to solve them, but the ability of sustainable development is bases on solid theory as the foundation. Market factors affect the change of teaching methods at the same time. The traditional teaching methods often take activities in classroom, using the method of teachers' teaching, students listening to lectures. Knowledge which students obtain mostly comes from indirect knowledge of books, and it is not conducive to the cultivation of practice ability and innovation ability. Therefore, the teacher need to use a lot of experiments and practice to teach, universities are required to invest more experimental apparatus equipments.

\section{Market promote the construction of "Double type" teachers}

According to the difference in talents training goal of the characteristic applied undergraduate, and the rich of course content and teaching methods, personnel composition and quality requirements for the teachers have a higher need. Especially in the process of teachers' team construction, teachers are required to not only have higher education, the theoretical level and teaching ability, but also have rich practical experience, operation ability and control ability, etc. Promoting the contingent of teachers of the characteristic applied undergraduate to the "Double type" development.

Characteristic applied undergraduate, on the basis of considering the market factors, should adopt positive measures in the teachers' team construction aspect. First of all, optimize the structure of teachers group. Adjusting the proportion of theory teaching teachers and practice teaching ones, and optimize the structure of teachers source. Bringing enterprise senior technicians and engineers, one of the marketing activities participants, into colleges and universities and enrich the teachers' group. They have strong complementary in knowledge structure, application, development, and innovation ability and work together to accomplishing teaching project. Second, improve the teacher assessment system. For those teachers who engaged in the theoretical teaching, must have corresponding time into production line inspection, investigation and study within a certain period of time, and make it into the assessment range. And professional teachers in practice teaching should regularly participate in learning, training, and strive to improve their professional level, and these will also be included in the assessment range. Finally, create a positive development environment for teachers. Encouraging teachers both in theory teaching and practice teaching to communicate with each other, and take part in all kinds of high level symposium, and investigation 
and practice. Vigorously bringing in high level professional talents as a academic leader, and hiring technical experts to guide and give lectures in the hope of building healthy competition mechanism and promoting teachers to improve their level, and also prompting characteristic applied undergraduate of "double type" teachers construction more reasonable and scientific.

E. Market factors have further promoted the development of cooperation between university and enterprise.

University-enterprise cooperation, developed in recent years, is a kind of ways to jointly cultivate the students for enterprise and school and an education model with the aim of cultivating applied talents suitable for industry, and enterprises by different education environment and education resources in schools and enterprise. This kind of education mode corresponds to the request in characteristic applied undergraduate that talented persons should have a solid professional knowledge and strong practical application ability. They are embodied in the following respects:

1) Personnel cultivating programs are conducted in the form of university-enterprise. Cooperation Characteristic applied undergraduate universities developing what kind of person, and how to cultivate the talents, is closely linked with the personnel cultivating programs. The personnel cultivating programs from formulation to implementation in Characteristic applied undergraduate universities, should be mutual participated by schools and enterprises. Personnel cultivating programs both require schools to consider the development principle of higher education and the development of student's body and mind as the starting point, and require enterprises to actively put forward demand of talent standard, both sides make joint in making implementation plan of every link in the process of personnel training.

2) The curriculum of university-enterprise cooperation: the complete curriculum system in Characteristic Applied undergraduate college includes two parts. Part of the courses should be borne by the school. Students are able to be taught with professional knowledge and sublimation of the theory after practice, with strong vitality and vigorous development. Another part of the courses should be participated by enterprises, mainly providing for the students the chance to involve in the production line. It has targeted to develop the students' application ability, can also stimulate the creation and the innovation potential of the students in the process of actual production practice.

3) The practice of university-enterprise cooperation. Practice is one of the important contents of university-enterprise cooperation and providing practice opportunities for students, and developing students' innovative practice ability is an important target of university-enterprise cooperation. Characteristic applied undergraduate should establish advanced production-teaching-research combination experiment training base. And design training program in accordance with the market and industry needs to cultivate the students' practical ability. So that the students can understand and experience the real work environment and process in the learning phase.

\section{References}

[1] Na Yang. Characteristic Applied Undergraduate Specialty Construction in Heilongjiang Province Research [D]. Harbin University of Science and Technology. 2012.

[2] Yaoxiu Lang. On the Specialty Construction of Applied Undergraduate Education [J]. Journal of Higher Education BBS, 2010, 5:3-5.

[3] Li Liu. Historical Investigation and Essence of "industry-university-institute" Cooperation Study [J]. Journal of Zhejiang University, 2002, (3).

[4] Rongwei Yang. Institutions of Higher Learning Professional Setting and Regulation Research [D]. East China Normal University, 2006.

[5] Jia Liu. Linkage Mechanism Study of University-Enterprise Cooperation [J]. Science and Technology Management Research, 2011, (7). 